\title{
Quality of life of an elderly person in the conditions of urban space
}

\author{
Olga A. Antipanova ${ }^{*}$, and Galina A. Barysheva ${ }^{2}$ \\ ${ }^{1}$ Tomsk Polytechnic University, 30, Lenin ave., Tomsk, 634050, Russia \\ ${ }^{2}$ International Scientific Educational Laboratory for the Improvement of Wellbeing Technologies of \\ Older Adults, Tomsk Polytechnic University, Tomsk, Russia
}

\begin{abstract}
The article considers the problem of the quality of life of the elderly in the city. A high-quality innovative urban environment is understood as a safe, comfortable space for living and recreation using smart city (home) technologies, adapted for all social groups of the population, including age groups. In modern Russia, the demographic situation requires paying attention to the compliance with city standards and criteria for the quality of life of seniors in a digital economy. This work is relevant today due to the increase in the retirement age. Principles of the active ageing effective strategy shall be based on the social partnership of state and elderly people. In the context of the foregoing, the quality of life of an elderly person is becoming increasingly important for the formation of a humanistic social urban environment in connection with the need to adapt a person to living conditions that change late in life.
\end{abstract}

\section{Introduction}

Over the past 60 years in many regions of the world (except Africa) there has been a noticeable tendency towards demographic aging mainly associated with a decline in the birth rate and mortality, which, along with a decrease in morbidity (especially in the EU) and disability, results in an increase in healthy life expectancy. Indeed, many European countries have the lowest birth rates and the highest life expectancy in the world [1-2].

Starting with the middle of the 20th century progressive aging of population in Russia due to a decrease in the birth rate has been observed. According to the Federal State Statistics Service, the share of the elders and seniors in Russia reached approximately $25.4 \%$ by 2020 . According to the Rosset-Boget-Garnier demographic ageing scale, a country will have the status of a demographically young country, if the share of people aged $60+$ years is less than $8 \%$. Population ageing starts with an indicator of $12 \%$, in Russia this indicator is exceeded almost twice.

The "Strategy of Action for Senior Citizens in the Russian Federation until 2025" includes the following key goals of the state social policy in relation to senior citizens: an increase in life expectancy, the standard of living and the quality of life of senior people, as well as stimulation of active longevity of senior citizens, their social and economic integration into

* Corresponding author: antipanova2020@gmail.com 
society. This allows ensuring a decent financial and social status of senior citizens, making the best use of their labor potential, creating conditions for the satisfaction of educational needs, increasing the level of financial literacy of senior citizens, developing a system of social services, etc [3].

\section{Materials}

Mercer international consulting firm annually ranks the best cities in the world. The statistical data is based on 39 diagnostic criteria, which are divided into 2 groups. The first group of indicators is the quality of life, the second one is the degree of personal security. In 2017, NewsEffector monitoring agency and the "Russian Regions" Regional Research Fund conducted social research "The Index of Happiness" in 100 cities of Russia. The main criteria are such indicators as the safety level, ecology. The indicator of material well-being was not at all a decisive factor that affects the happiness of Russians. The first lines of the rating were occupied by such cities as Grozny, Tyumen, Kazan, Novorossiysk.

A high-quality innovative urban environment means a safe, comfortable space for living and recreation with the use of the technologies of a smart city (home), which is adapted for all social groups of the population, including age groups. In modern Russia the demographic situation requires paying attention to the compliance with city standards and criteria for the quality of life of seniors in a digital economy.

The problem of urban comfort for seniors is not new. In 1947, Ben Schleifer (USA) created a city of old people and for old people in Arizona. Although the first attempt was unsuccessful, in 195523 older couples brought the idea to life. The project was given renewed momentum after the financial participation of Dell Webb, who thought out the infrastructure of the city that is most suitable for this age group. Hospitals, swimming pools, golf courses, shopping and sports centers were built there first; much attention was paid to qualified personnel familiar with the age-related specifics. At the moment there are twenty such cities. Some gerontologists claim that such specialized urban-type settlements sustain life by an average of five years. Low local taxes help older people with limited financial resources. Medical care is provided under state insurance. In these settlements all risks are significantly reduced: crime is practically absent, problems related to adequate late-life employment are easier to solve, a high concentration of older people determines the profitability of existing leisure facilities. High social activity of the elderly contributes to the prevention of aging. They not only serve in almost all capacities in the city, but also participate in self-sufficiency: the elderly work at vegetable farms to the best of their physical abilities; products are distributed according to the efforts put into them. The main source of income here are pensions, return on shares and income from letting immovable products. One of the most famous settlements for the elderly is American Sun City [4-5].

The very idea of humanizing the urban space arose in the 1960s. This idea has its own experience in solving problems related to city comfort for the elderly. Over the years cities for the elderly and specialized settlements have been created in European countries, for example, in England, in several countries of continental Europe, in Australia [6].

Already in the 1970s gerontological researchers discovered another problem related to the ability of older people to change rapidly with the world of digital technology. And this problem is reflected today [7]. The main sociological theories of society aging and the role of an elderly person are given in table 1.

Table 1. The main sociological theories of society aging and the role of an elderly person.

\begin{tabular}{|l|l|l|}
\hline Theories & Authors & Theory content \\
\hline
\end{tabular}




\begin{tabular}{|c|c|c|}
\hline Theory of Ageism & $\begin{array}{c}\text { R. Butler } \\
\text { M. Mead } \\
\text { L. Foyer } \\
\text { K. Victor } \\
\text { S. Con }\end{array}$ & $\begin{array}{c}\text { This concept reflects social } \\
\text { discrimination and antagonism of } \\
\text { younger groups against older people. }\end{array}$ \\
\hline Theory of Subculture & A. Rose & $\begin{array}{c}\text { The theory suggests that } \\
\text { "discrimination" towards older people } \\
\text { and their sense of community provide } \\
\text { the basis for the emergence of a } \\
\text { subculture of old age. In practical } \\
\text { terms the author of the theory } \\
\text { proposes to proceed to the creation of } \\
\text { settlements, residential houses for the } \\
\text { elderly. }\end{array}$ \\
\hline Theory of Activity & M. Maddox & $\begin{array}{c}\text { The main aspect is a positive } \\
\text { relationship between the level of } \\
\text { activity and life satisfaction. Old } \\
\text { people should be involved in the life } \\
\text { of society; this should mean that the } \\
\text { more active the person is, the more } \\
\text { satisfied with life he/she is. }\end{array}$ \\
\hline Theory of Socio-Emotional & L. Carstensen & $\begin{array}{c}\text { The theory considers the relationship } \\
\text { of changes in the aspect of reducing } \\
\text { social contacts throughout life as a } \\
\text { result of changes in the motivation } \\
\text { system [8]. }\end{array}$ \\
\hline
\end{tabular}

The presented theories touch upon the problem of adaptation of elderly people, who are forced to change views in the conditions of institutional transformations. In fact, we are talking about secondary socialization. After retirement the circle of contacts gradually narrows, previous social roles disappear; the economic activity is significantly reduced. This is largely due to changes in the human motivation system throughout life. Scientific papers published before the 1990s often mention that society disrespects old age.

The concept of consolidation of the urban environment is today the mainstream in science. A modern European city is a compact (smart) densely built-up grassed and landscaped city. In addition to lower energy costs, a significant reduction in the need to move around the city, creation of additional opportunities to ensure the safety of residents, a compact densely built-up city stimulates an intensive social life. It provides for walking distance to all necessary services, starting with trade and consumer services and ending with educational and medical services [9].

Strategies are needed to create better conditions in urban spaces. R. Demiri and A. Kochi argue that such strategies are used to implement actions, projects and programs aimed at achieving various goals, such as [10]:

i. Improving the quality of the environment in urban spaces by reducing $\mathrm{CO} 2$ and waste.

ii. Optimization of energy consumption by increasing the efficiency and production of renewable energy.

iii. Improving the quality of life by providing the best public and private services, such as local public transport, medical services, etc.

Smart home is the key to the safety of the elderly. One of the most important problems of modern society is to ensure a high quality of life for people with special needs (elderly, people with disabilities, migrants, young mothers). In this regard the availability of technologies that can provide timely medical care is extremely important. Smart devices that ensure the safety of older people are gaining great popularity, including in Russia. For example, "panic 
buttons", which, if necessary, allow to instantly contact emergency services or the selected number (of a relative, social worker).

As a share of elderly people is continuously growing all over the world, policy makers face new challenges of tailoring social policy to the needs of older generation. In 2016 Tomsk the team of International Scientific-Educational Laboratory for the Improvement of Wellbeing Technologies of Older Adults of Tomsk Polytechnic University has organized two expert seminars with the participation of older people and social workers and officials. The results of expert seminars allowed making up a set of recommendations for a legislative body of Tomsk region [11].

The importance of an urban environment favorable for older people is considered in the study of S. Tiraphat, K. Pelezer [12]. The work was aimed at exploring the relationship between the environment favorable to old age and the quality of life among older people in Thailand. The researchers interviewed 4,183 elderly people ( $\geq 60$ years old) using multi-stage systemic sampling in four regions of Thailand. The WHO Quality of Life Scale was used as the resulting variable. Independent variables took into account age characteristics of older people and included socio-demographic factors, possible health problems, and the environment. The multifactor model included such indicators of the quality of life as the accessibility of the pedestrian zone, district aesthetics, district services accessibility, district security, social trust of the district, social support of the district and social cohesion of the district. The authors of the study revealed a positive relationship between the social trust of neighbors and social support, social cohesion. Social cohesion and social support among the elderly can enhance the well-being of older people by providing emotional support, boosting self-esteem and enhancing mutual respect. Elderly people with the highest perception of trust in their district have higher rates of the quality of life related to mental health compared to other districts with the lowest perception of trust. Researchers believe that a high level of "trust in others" will reduce negative emotions, stress and anxiety. These people are more likely to increase their sense of security, which leads to improved mental health. The analysis of the "district aesthetics" indicator showed that residents living in a more aesthetically pleasing district (green district) have significantly better mental health conditions, i.e. are more satisfied with life. It is reasonable to assume that residents living near green spots of the city will devote more time to physical activity and be able to improve their physical condition and general state.

The work of T. Buffel and S. Philipson presents a critical view of the development of age cities in the EU countries by examining the policies of these cities in the context of changes caused by globalization [13]. The subject is explored by studying, firstly, the arguments underlying the development of an age-specific approach in these cities, secondly, pressure factors affecting the urban environment and their relevance for older people and, thirdly, problems associated with improving the urban environment for older people. The authors come to a conclusion that it is necessary to combine the conceptual model of an "age-specific" city with an analysis of the economic and social forces transforming the urban environment.

Gerontologist R. Gobbens devoted his research to environmental factors that play an important role in the quality of life of older people, because older people often have difficulties in maintaining physical, psychological and social health [14]. In this study the author set himself the following goals: 1) to develop a measuring tool designed to assess factors of older people's perception of their environment; 2) to study the relationship of these environmental factors with the quality of life in the areas of physical health, psychological, social relations and the environment. 1031 Dutch residents aged 65 years and older took part in this study. The respondents filled in a web-based questionnaire consisting of 42 questions. According to the survey findings, seven scales consisting of 3-9 environmental elements were constructed. For example, housing, facilities, residents, surroundings, noise. This study showed that many environmental factors are associated with the quality of life of older 
people. To support the independent living of older people, health and social welfare professionals, as well as policymakers, may need to hold activities focusing, in particular, on housing and residents.

House construction is central to Australia's "active longevity" strategy, in which safe, adequate and affordable housing is defined as a socially and economically valuable form of conditions for living. This strategy considers housing as an essential basis for successful aging on an individual and national scale, emphasizing that housing is a place that provides a stable and safe environment, as well as a place for active aging [15].

Another problem was identified - it is loneliness of elderly people in big cities. To the maximum extent it is typical for two "polar" age groups: adolescents and the elderly. Moreover, adolescents are faced with this phenomenon even more often than representatives of the older generation. For the greater part loneliness of elderly people is a systemic phenomenon that occurs under the influence of an invisible barrier conditionally dividing a person's life into periods "before retirement" and "after retirement". In light of this, regular communication and maintaining intergenerational relations are of great importance.

There is one more problem, which can conditionally be called the "intergenerational conflict". The results of the study conducted in the late 1990s by American scientists C. Edwards and J. Wetsler are representative. They argued that young people see the elderly as a potential threat, anxiety caused by the factors that accompany aging (feebleness, weakness, possible physical disability). C. Edwards and J. Westler confirmed this hypothesis with research, and they believed that young people overcome the perception of older adults as a threat and their anxiety is reduced, if they initially perceive themselves as part of the same group with the elderly, which they will join in the future. This problem can be solved with the help of generational interaction programs [16].

In the context of the foregoing the quality of life of an elderly person is becoming increasingly important for the formation of a humanistic social urban environment in connection with the need to adapt a person to the conditions of existence that change late in life.

\section{Results and discussion}

It was revealed that the quality of life of elderly people in modern cities directly depends on the formation of the institutional environment, inclusion of the older generation in the regional community, and specific actions, as well as conditions, for the provision of which local governments are responsible. The main directions of their work should be reflected in cooperation with regional and federal state authorities. The main recommended urban environment components for the safe living of the elderly are as follows are given in table 2 .

Table 2. The main recommended urban environment components for the safe living of the elderly.

\begin{tabular}{|c|c|}
\hline $\begin{array}{c}\text { Urban } \\
\text { environment } \\
\text { components }\end{array}$ & The main recommendations \\
\hline $\begin{array}{c}\text { (a) Advanced } \\
\text { medicine }\end{array}$ & $\begin{array}{c}\text { It includes a developed material and technical base } \\
\text { and an innovative network of care-giving institutions } \\
\text { for the elderly. For example, "panic buttons", which, } \\
\text { if necessary, allow to instantly contact emergency } \\
\text { services or the selected number }\end{array}$ \\
\hline $\begin{array}{c}\text { (b) The innovative } \\
\text { infrastructure } \\
\text { available for the } \\
\text { elderly }\end{array}$ & $\begin{array}{l}\text { For example, cultural and leisure, sports and } \\
\text { recreation, social and educational infrastructure. An } \\
\text { elderly person stops driving or lives at a respectful } \\
\text { distance from the bus stop, cannot reach the } \\
\text { destination point due to health reasons, is forced to }\end{array}$ \\
\hline
\end{tabular}




\begin{tabular}{|c|c|}
\hline & $\begin{array}{c}\text { become a house body. In some regions large-scale } \\
\text { strategies are implemented to improve transport } \\
\text { accessibility (new stops and crosswalks are added, if } \\
\text { needed). Measures aimed at improving the quality of } \\
\text { sidewalks and ensuring the safety of busy } \\
\text { intersections really help citizens growing older to } \\
\text { move around }\end{array}$ \\
\hline $\begin{array}{c}\text { It involves the creation of an affordable urban space } \\
\text { and the provision of housing for older people. When } \\
\text { developing the concept of a "smart city", the } \\
\text { administration should adapt comprehensive plans of } \\
\text { an urban space to the needs of elderly people }\end{array}$ \\
\hline $\begin{array}{c}\text { (d) Favorable } \\
\text { environmental } \\
\text { conditions }\end{array}$ & $\begin{array}{c}\text { Strict adherence to environmental protection } \\
\text { measures by the state and transfer of industrial } \\
\text { enterprises outside the city }\end{array}$ \\
\hline $\begin{array}{c}\text { (e) Generations } \\
\text { interaction } \\
\text { programs }\end{array}$ & $\begin{array}{c}\text { They solve the problem of loneliness through inter- } \\
\text { generational skills-sharing events. In connection with } \\
\text { retirement there are more opportunities for changing } \\
\text { activities. Also, this method will help elderly people } \\
\text { develop technological skills and will make it possible } \\
\text { to use technology and transport innovations }\end{array}$ \\
\hline $\begin{array}{c}\text { To ensure a decent life for the elderly, it is necessary } \\
\text { to provide an effective system of benefits and } \\
\text { allowances, an open database of vacant jobs for the } \\
\text { elderly }\end{array}$ \\
\hline $\begin{array}{c}\text { (g) Provision of } \\
\text { consultations to the } \\
\text { elderly }\end{array}$ & $\begin{array}{c}\text { For example, professional retraining, psychological } \\
\text { trainings, etc. }\end{array}$ \\
\hline
\end{tabular}

The new innovative quality of the urban environment should take into account the needs of various categories of citizens, in particular, elderly people, and a transition from the traditional mono-model of the city to a polycentric model, which focuses on the individual form of social communication, free choice of places of residence, life and leisure, is supposed.

\section{Conclusion}

As a result of the study, components of the urban environment were recommended. These components will solve the main problems (comfort, security, adaptation to digital technologies, recreation, leisure, loneliness) and will be favorable for elderly people to live in urban spaces. Local governments will have to consider options for creating favorable living conditions for people, to develop and implement effective social policies.

The study was supported by the Russian Science Foundation (project №19-18-00300).

\section{References}

1. E. Power, Housing, home ownership and the governance of ageing. Geographical Journal, 233-246 (2017)

2. T.N. Kovaleva, Social factors of dehumanization of modern urban space, Society: philosophy, history, culture. 2,17-26 (2014) 
3. V.N. Barsukov, The consequences of demographic aging and the resource potential of the population of the "Third" age, Problems of development of the territory. 3(89), 9399 (2017)

4. A. Walker, T. Maltby, Active ageing: A strategic policy solution to demographic ageing in the European Union. International Journal of Social Welfare, 21, S117-S130 (2012),

5. M. Batty, K.W. Axhausen, F. Giannotti, A. Pozdnoukhov, A. Bazzani, M. Wachowicz, Y. Portugali, Smart cities of the future, The European Physical Journal Special Topics. 214(1), 481-518 (2012)

6. J.E. Morley, Aging Successfully: The Key to Aging in Place, 16(12), 1005-1007 (2015)

7. L.S. Feuer, The Conflict of Generation. The Character and Significance of Student Movement (NewYork, 1969)

8. L.L. Carstensen, Motivation of social contact across the life-span (Lincoln: University of Nebraska Press, 1993)

9. A.Murphy, P. Kowal, M. Albertini et al. Family transfers and long-term care: An analysis of the WHO Study on global AGEing and adult health (SAGE), Journal of the Economics of Ageing. 12, 195-201 (2018)

10. A. Cocchia, Smart and digital city: A systematic literature review. In R.P. Dameri and C. Rosenthal-Sabroux (Ed.), Smart City, pp. 13-43 (2014)

11. O.P. Nedospasova, G.A. Barysheva, S.V. Berkalov, V.A. Malanina, Ageing Population: Challenge for New Quality of Social Policy. The European Proceedings of Social and Behavioural Sciences, 26, 77-84 (2017)

12. S. Tiraphat, K. Peltzer, The Role of Age-Friendly Environments on Quality of Life among Thai Older Adults, Int. J. Environ. Res. Public Health 14(3), 282 (2017)

13. T. Buffel, C. Phillipson, Can global cities be 'age-friendly cities'? Urban development and ageing populations. Cities. 55, 94-100 (2016)

14. Robbert J J Gobbens, Associations of Environmental Factors With Quality of Life in Older Adults, The Gerontologist, 58(1), 101-110 (2018)

15. A. C. Lyons, J. Grable, S-H. Joo, A Cross-Country Analysis of Population Aging and Financial Security. Journal of the Economics of Ageing. 12, 96-117 (2018)

16. K. Edwards, J. Wetzler, Too young to be old: The roles of self-threat and psychological distancing in social categorization of the elderly, Journal of Language \& Social Psychology, 12(3), 207 - 223 (1998) 